\title{
TENDERNESS OF BEEF AS AFFECTED BY THE AGE OF ANIMAL
}

\author{
Eini Laakkonen ${ }^{1}$, G. H. Wellington, and J. W. Sherbon \\ Departments of Animal Science and Food Science, Cornell University ${ }^{2}$, \\ Ithaca, New York 14850, U.S.A.
}

Received March 26, 1969

It is well known that the older bovine animals have less tender meat than the young ones. There are two major factors in meat which contribute to the toughness: the contraction stage of the muscle, and the connective tissue. So called »actomyosin-toughness» is suggested to be due to configurational changes of actin and myosin (MARsh et al. 1966), which Herring et al. (1967) have shown to be highly related with shortened sarcomeres.

Connective tissue of the muscle is mainly collagen, although in certain muscles there are rather large quantities of elastin as well (RAmsbotrom and Strandine 1948). Several studies have indicated that there is no systematic increase in the amount of collagen as age increases (Wilson et al. 1954, Goll et al. 1963, Hrll 1966). Hill (1966) found that collagen solubility in 1/4 strength Ringer's solution decreased with increasing chronological age of the animal, and suggested therefore that the aging of animal affects the collagen solubility. This could be the reason why the meat from older animals is more tough than that from younger ones, in spite of no distinct increase in the amount of collagen. VEIS and ANESEY (1965) suggested that the enhancement of intermolecular bonding between $\alpha_{1}$ sub-unit chains may be a characteristic feature of the maturation of collagen. They also indicated that mature collagen fibrils may be represented as assemblies of tropocollagen molecules joined together by a variety of intermolecular covalent crosslinkages to form vast asymmetrical polymer networks.

With this theoretical background in mind, the present study was performed in order to compare the extent of the differences in tenderness and the water-holding capacity of muscles from old Holstein cows with those from young Hereford steers while an effort was made to keep the effects of connective tissue toughness and actomyosin-toughness as low

\footnotetext{
1 Present address - c/o Institute of Meat Technology, University of Helsinki, Helsinki 71, Finland.

2 This research was carried out in part under Contract No. 12-14-100-8903 (73) with the Agricultural Research Service, U. S. Department of Agriculture, administered by the Eastern Utilization Research and Development Division, Philadelphia, Pennsylvania 19118.
} 
as possible. This kind of information is necessary for improvements in both industrial and home use of meat, especially in countries where old dairy cow meat is commonly used.

\section{Experimental methods}

The experimental animals were slaughtered at the Department of Animal Science of Cornell University. Longissimus dorsi and rectus femoris muscles from three Hereford steers, age about 20 months, of Prime - or Choice + Grade with warm carcass weight of 286 to $335 \mathrm{~kg}$, and from three Holstein cows, age 108 to 126 months, and warm carcass weight from 244 to $302 \mathrm{~kg}$ were used.

The carcasses were kept in a cooler at $0 \pm 1 \mathrm{C}$. After 5 to 7 days, the muscles to be studied were separated, packed into Cry-O-Vac bags, (Dow Chemical Co., Midland, Mich., U.S.A.) vacuumized, and kept on the shelf in a cooler at $0 \pm 1 \mathrm{C}$. The steer muscles were aged for two weeks, and the old cow muscles for four weeks.

The muscle to be studied was trimmed aseptically of fat and epimysium. Then it was cut into about $2.5 \mathrm{~cm}$ slices weighing $100 \pm 30 \mathrm{~g}$. The slices were put into Cry-O-Vac $(134 \times 425 \mathrm{~mm})$ bags, vacuumized, and sealed. Two experiments with Hereford steers were carried out in Vacu gas (ethylenoxide) sterilized polyethylene bags.

Tenderness was measured as shear value in $1 \mathrm{~b}$ with Warner-Bratzler apparatus (Chatillon, New York, U.S.A.). The diameter of each test core was $2.5 \mathrm{~cm}$, and an attempt was made to keep the axis of the core parallel to the muscle fibers. Three such cores were taken from each portion of meat at each sampling point in the cooking schedule. Each core was sheared first into two halves, and these were sheared again, thus giving nine shear value readings for each sample.

The Warner-Bratzler instrument consists of a 1-mm thick blade with a triangular opening large enough to hold a cylindrical sample of meat (Szczesniak and Torgeson 1965). The blade is led through a slit between two shear bars. Force is applied to the blade, and the amount of force required to shear the sample is measured with a dynamometer. A shearing speed of $225 \mathrm{~mm} / \mathrm{min}$ is used. The force is read in pounds. Doty and PIERcE (1961) stated that this objective method would be satisfactory for most meat quality studies. BRATZLER (1949) pointed out the importance to control the following variables: degree of doneness of the cooked meat, uniformity of sample size, direction of muscle fibers, presence of connective tissue and fat deposits, temperature of sample, and speed of shearing. These factors were controlled as closely as possible during this study.

The weight loss during cooking of meat is largely water, especially in low-fat pieces of meat, and therefore the weight loss reflects the water binding ability of the meat proteins. Meat samples were weighed before and after heating, and the weight loss was computed as percent of the fresh weight.

The heating program was scheduled to minimize the effect of both actomyosin-toughness and connective tissue-toughness. Therefore low temperatures and a slow rate of heating were used (LAAKKonen et al. 1969). The muscle slices in the vacuumized Cry-O-Vac bags were put into a water bath where the temperature was rising such that the rate of temperature increase in the meat was $0.1 \mathrm{C} / \mathrm{min}$. Heating of the water bath was started at $30 \mathrm{C}$, and ended at $60 \mathrm{C}$, where it was maintained until $10 \mathrm{hr}$ total cooking time had passed. Samples were taken after 3 or $4 \mathrm{hr}$, and then each hour, as long as there was enough meat available. 
One portion of each muscle was used as a controlled cooking sample following a method similar to that of Marsh, Woodhams and LeEt (1966). This sample was first tempered $1 \mathrm{hr}$ at $30 \mathrm{C}$ in a water bath, then heated up to $80 \mathrm{C}$ at a rate of $0.8 \mathrm{C} / \mathrm{min}$, and kept at this temperature for $1 \mathrm{hr}$.

\section{Results and discussion}

Fig. 1 shows the changes in tenderness during the low temperature heating of the longissimus dorsi muscle. The data represent the means and standard deviations of 27 measurements, except when the number of measurements is indicated in parentheses. The shear values for the young steer muscles were considerably lower than those for the old cow muscles throughout the heating period.

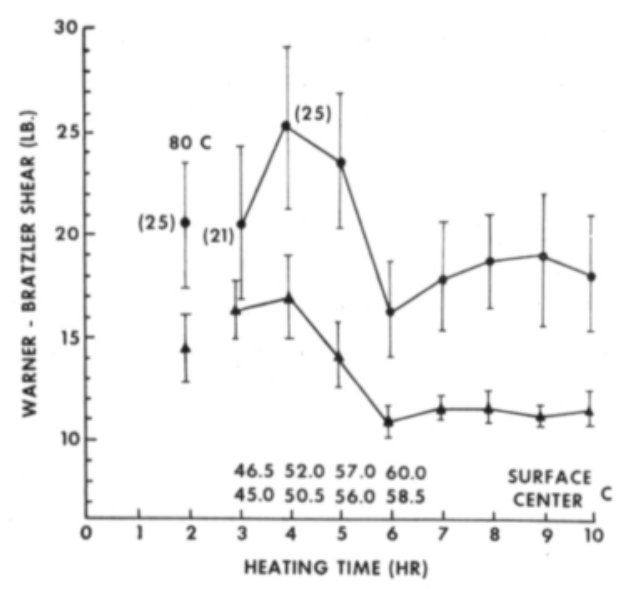

Figure 1. Changes in shear values in the longissimus dorsi muscles of three aged Holstein cows and three young Hereford steers, heated at 0.1 $\mathrm{C} / \mathrm{min}$ to $60 \mathrm{C}$, and held for $10 \mathrm{hr}$ total heating time. The data represent means and standard deviations of 27 measurements, except when the number of measurements is indicated in parentheses. Legend: old Holstein cow, $\boldsymbol{\Delta}-\boldsymbol{\Delta}$ young Hereford steer.

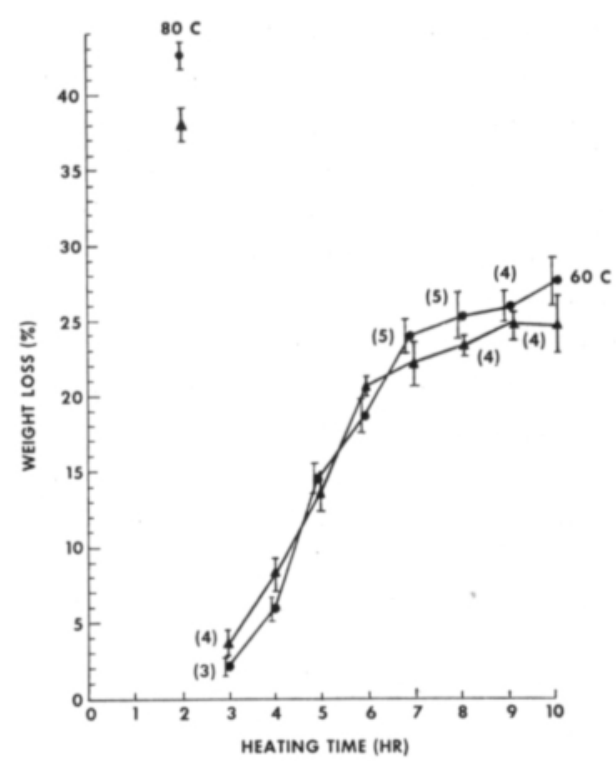

Figure 2. Changes in the water-holding capacity in the longissimus dorsi and rectus femoris muscles of three aged Holstein cows and three young Hereford steers, heated at $0.1 \mathrm{C} / \mathrm{min}$ to $50 \mathrm{C}$, and held for $10 \mathrm{hr}$ total heating time. The data represent means and standard deviations of six measurements, except when the number of measurements is indicated in parentheses. Legend: - old Holstein cow, $\boldsymbol{\Delta} \longrightarrow \boldsymbol{\Delta}$ young Hereford steer.

Cover and Hostetler (1960) have reported that heating causes a decrease in tenderness in muscles containing small amounts of connective tissue. This phenomenon was seen between the 3rd and 4th $\mathrm{hr}$ of heating when the temperature changed from 46.5 to $52.0 \mathrm{C}$ on the surface, and from 45.0 to $50.5 \mathrm{C}$ in the center of the meat samples. The toughening effect seemed also to be more distinct in the old cow muscle than in the young steer muscle. From the 4 th to the 6 th $\mathrm{hr}$, with a temperature increase from 52.0 to 60.0 on the surface, 
and from 50.5 to 58.5 in the center, there was a considerable decrease in shear value readings in the muscles of both the old and young animals. This was obviously due to the shrinkage of collagen (Bear 1952, Draudt et al. 1964, Paul et al. 1966). During prolonged heating at $60 \mathrm{C}$ there was a slight increase in the shear values which may be due to the effect of heat on the meat proteins, and this may also partly be due to the decrease of water-holding capacity as seen in Fig. 2.

The decrease in shear value was more distinct in longissimus dorsi of the old cows, $9 \mathrm{lb}$, as compared with the same muscle from the young steers, $6 \mathrm{lb}$. It seems likely that the cross-linkages in the collagen molecules of the old cows have caused the higher readings even after shrinkage of collagen. The more pronounced increase in tenderness in the old cow muscles may have partly been due to the possible enzymatic activity during the aging of meat, since the muscles from the old cows were aged or conditioned twice as long as those from the young steers.

The shear values of the $80 \mathrm{C}$ heated controls of the young steer muscles were significantly higher, at the probability level of $0.1 \%$, than the $6 \mathrm{hr}$ and $10 \mathrm{hr}$ samples at $60 \mathrm{C}$. The higher shear value readings of the $80 \mathrm{C}$ heated controls were obviously due to the higher final temperature which caused more severe coagulation and shrinkage of the muscle fiber proteins (Rrtchey and Hostetler 1964, Hostetler and Landmann 1968). However, even in these samples, there was similar difference between the young and old animals as in those heated at $60 \mathrm{C}$.

Fig. 2 shows the changes in weight loss, i.e., the changes in the water-holding capacity of samples from both longissimus dorsi and rectus femoris muscles from three old Holstein cows and three young Hereford steers. Tenderness and water-holding capacity have been shown to be interrelated (Hamm 1953). This is confirmed by comparing the data in Table 1

Table 1. Comparison of weight losses (\%) between muscle samples heated to $60 \mathrm{C}$ at $0.1 \mathrm{C} / \mathrm{min}$ and held $4 \mathrm{hr}$ and control samples heated to $80 \mathrm{C}$ at $0.8 \mathrm{C} / \mathrm{min}$ and held $1 \mathrm{hr}$.

\begin{tabular}{lccc}
\hline Animals & \multicolumn{2}{c}{ Heating } \\
$10 \mathrm{hr}$ & Control \\
\hline & & & \\
& & & \\
Young Hereford Steers & $21.90 * * *$ & $25.97 * * *$ & 38.66 \\
Old Holstein Cows & $18.50 * * *$ & $27.49 * * *$ & 42.54 \\
\hline
\end{tabular}

$* * * \mathrm{P}<0.001$

and in Fig. 2 with those in Fig. 1. Between the 6 th and the 7 th hr of heating, there was a distinct weight loss in the old cow muscle which was also reflected in the tenderness of the samples of the same hours. This trend continued, although to a smaller extent, during the further heating, but after $10 \mathrm{hr}$, in spite of increased weight loss, there was a small decrease in shear value readings. The latter may be due to enzymatic activity which may occur even at $60 \mathrm{C}$ (LAAKKonen 1969). In the young steer muscles, the weight loss was smaller, and this may partly be the reason why there was hardly any change in the shear value readings after the 6 th $\mathrm{hr}$ of heating.

Table 1 shows that the $6 \mathrm{hr}$ and $10 \mathrm{hr}$ weight loss differences, as compared with the 
$80 \mathrm{C}$ heated controls, were each significant at the $0.1 \%$ level. The heavier shrinkage of the controls had also caused more meat juices to squeeze out of the samples. This was more distinct in the old cow muscles.

The values for the water-holding capacities of the longissimus dorsi and rectus femoris muscles from both young and old animals seemed to follow more closely to each other than those of tenderness. However, the water-holding capacity of the young steer muscles appeared to be better than that of the old cow muscles, except at the early phases of heating when the temperature was below $60 \mathrm{C}$. Table 1 shows that at the end of heating at $60 \mathrm{C}$, i.e., after $10 \mathrm{hr}$ total heating time, and after heating at $80 \mathrm{C}$, after $2 \mathrm{hr}$ total heating time, there was a clear difference between the water-holding capacities of the muscles of the old and young animals.

\section{Summary and conclusions}

Samples from longissimus dorsi and rectus femoris muscles from three old Holstein cows and three young Hereford steers were heated at a rate of $0.1 \mathrm{C} / \mathrm{min}$ from 30 to $60 \mathrm{C}$, and held for $4 \mathrm{hr}$ at the latter temperature to obtain total heating time of $10 \mathrm{hr}$. The young Hereford steer muscles were more tender, and showed better water-holding capacity throughout the experiments than the same muscles from the old Holstein cows. The same differences were also seen in samples heated to $80 \mathrm{C}$ at a rate of $0.8 \mathrm{C} / \mathrm{min}$, and held for $1 \mathrm{hr}$.

\section{REFERENCES}

BeAR, R. S. 1952. The structure of collagen fibrils. In Adv. in Protein Chem. 7: 69-160.

Bratzler, L. J. 1949. Determining the tenderness of meat by the use of the Warner-Bratzler method. Proc. 2nd Ann. Reciprocal Meat Conf: 117-120.

Cover, S. and Hostetrer, R. L. 1960. An examination of some theories about beef tenderness by using new methods. Bull. 947. Texas Agr. Expt. Sta., Austin, Texas, U.S.A.

Doty, D. M. and Pierce, J. C. 1961. Beef muscle characteristics as related to carcass grade, carcass weight, and degree of aging. U.S. Dept. Agr. Tech. Bull. No. 1231.

Draudt, H. N., Machlik, S. M. and Rrmstidt, C. D. 1964. Effect of cooking time and temperature on tenderness and papain action in beef. Proc. 16th Res. Conf. Circ. No. 76: 115-127. Amer. Meat Inst. Found., Chicago, Ill., U.S.A.

Goll, D. E., Bray, R. W. and Hoekstra, W. G. 1963. Age-associated changes in muscle composition. The isolation and properties of a collagenous residue from bovine muscle. J. Food Sci. 28: 503.

Hamm, R. 1953. Die Wasserbindung des Fleisches und ihre wirtschaftliche Bedeutung. Deut. Lebensm. Rundschau 49: 153.

Herring, H. K., Cassens, R. G., Suess, G. G., Brungardt, V. H. and Briskey, E. J. 1967. Tenderness and associated characteristics of stretched and contracted bovine muscles. J. Food Sci. 32: 317.

Hrll, F. 1966. The solubility of intramuscular collagen in meat animals of various ages. Ibid. $31: 161$.

Hostetler, R. L. and Landmann, W. A. 1968. Photomicrographic studies of dynamic changes in muscle fiber fragments. 1. Effect of various heat treatments on length, width and birefringence. Ibid. 33: 468 .

LAAKKonen, E. 1969. Collagenolytic activity and water-holding capacity as factors affecting tenderness during low-temperature long-time heating of bovine muscle. $\mathrm{Ph}$. D. thesis, Cornell University, Ithaca, New York, U.S.A.

LaAkkonen, E., Wellington, G. H. and Sherbon, J. W. 1969. Tenderizing effect of low-temperature long-time heating on bovine muscle. 1. Changes in tenderness, water-holding capacity, $\mathrm{pH}$, and the amount of water-soluble fraction. J. Food Sci. (In press). 
Marsh, B. B. and Leet, N. G. 1966. Studies in meat tenderness. III. The effects of cold shortening on tenderness. Ibid. 31: 450 .

Marsh, B. B., Woodhams, P. R. and Leet, N. G. 1966. Studies in meat tenderness. I. Sensory and objective assessments of tenderness. Ibid. 31: 262.

Paul, P. C., Buchter, L. and Wierenga, A. 1966. Solubility of rabbit muscle proteins after various timetemperature treatments. J. Agr. Food Chem. 14: 490.

Ramsbottom, J. M. and Strandine, E. J. 1948. Comparative tenderness and identification of muscles in wholesale beef cuts. Food Res. 13: 315.

Ritchey, S. J. and Hostetler, R. L. 1964. Relationships of free and bound water to subjective scores for juiciness and softness and to changes in weight and dimensions of steaks from two beef muscles during cooking. J. Food Sci. 29: 413.

Szczesniak, A. S. and Torgeson, K. W. 1965. Methods of meat texture measurements viewed from the background of factors affecting tenderness. Adv. in Food Res. 14: 33.

Vers, A. and ANEsEy, J. 1965. Modes of intermolecular cross-linking in mature insoluble collagen. J. Biol. Chem. 240: 3899.

Wilson, G. D., Bray, R. W. and Phillips, P. H. 1954. The effect of age and grade on the collagen and elastin content of beef and veal. J. Animal Sci. 13: 826.

\section{SELOSTUS}

\section{ELÄIMEN IÄN VAIKUTUS NAUDANLIHAN MUREUTEEN}

Eini LaAkkonen, G. H. Wellington ja J. W. Sherbon

Cornell yliopiston Kotieläintieteen ja Elintarviketieteen laitokset, Ithaca, New York, U.S.A.

Kolmesta vanhasta Holstein-lehmästä ja kolmesta nuoresta Hereford-härästä otettuja longissimus dorsi- ja rectus femoris-lihasnäytteitä kuumennettiin $0.1^{\circ} \mathrm{C} / \mathrm{min}$ nopeudella $30^{\circ}$ :sta $60^{\circ}$ :een, ja pidettiin viimeksi mainitussa lämpötilassa, kunnes kokonaiskuumennusaika oli $10 \mathrm{t}$. Nuorten Hereford-härkien lihakset olivat mureampia ja niiden vedensidontakyky oli parempi kuin vanhojen Holstein-lehmien samojen lihasten vastaavat ominaisuudet näissä kokeissa. Samat eroavuudet havaittiin myös näytteissä, jotka kuumennettiin $80^{\circ}$ :een nopeudella $0.8^{\circ} \mathrm{C} / \mathrm{min}$ ja pidettiin tässä lämpötilassa $1 \mathrm{t}$. 